\title{
Lactobacillus casei isolated from Human Milk and Three Natural Agents act as Antibacterial against Gram Negative Pathogenic Bacteria isolated from Infected Eye
}

\author{
Enas Ibrahim Jasim, Basam Basim Al-Fraji* and Duaa Suhail Shawket
}

\author{
Department of Biology, Collage of Science, University of Al-Mustansiriyah, Baghdad, Iraq \\ *Corresponding author
}

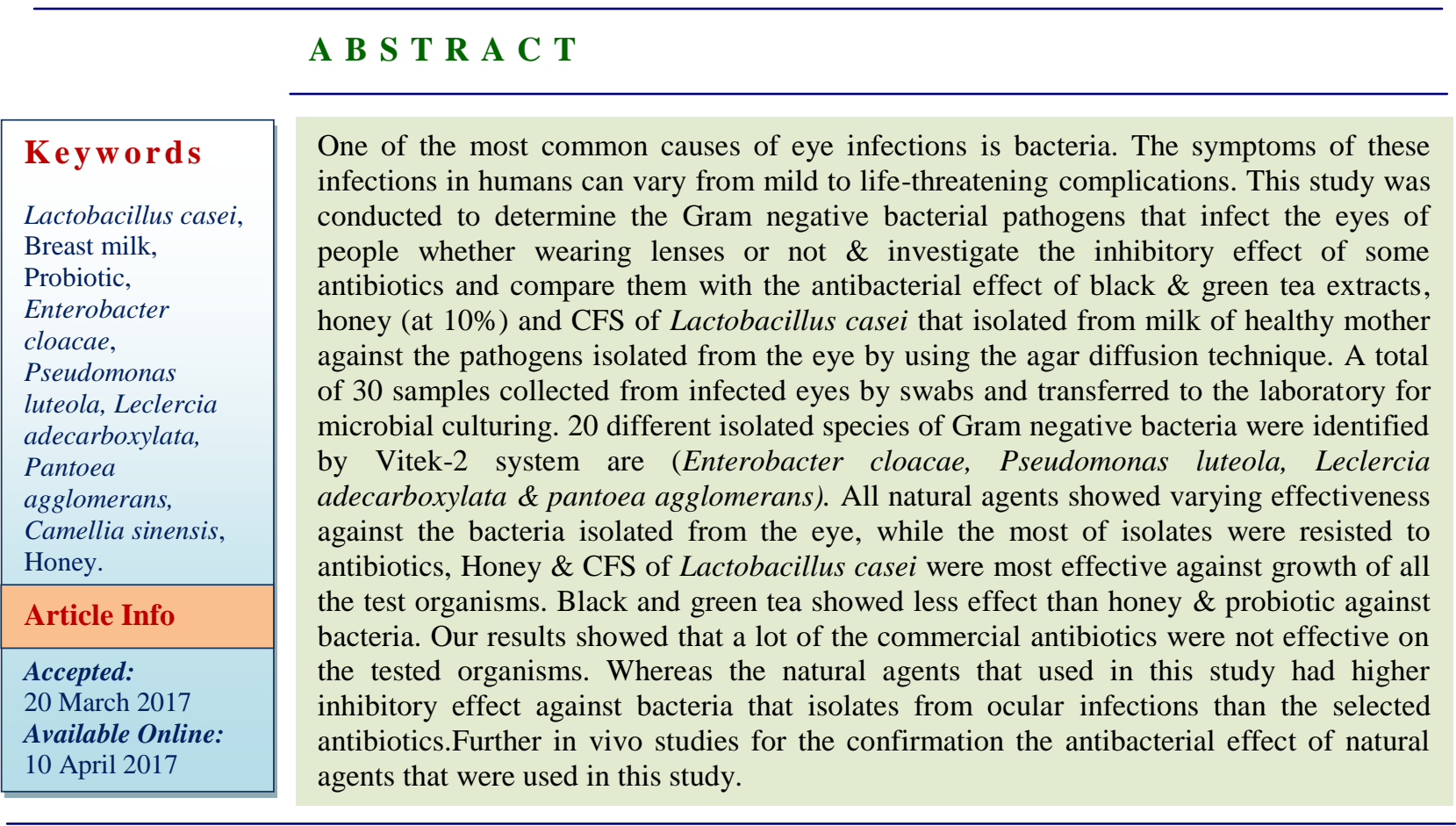

\section{Introduction}

Eye is one of the sense organ which is important throughout our life (Dagnachew et al., 2014). Pathogenic microorganisms cause diseases to the eyes due to their virulence and host's reduced resistance from many factors such as personal hygiene, living conditions, socio-economic status, nutrition, genetics, physiology, and age (Ubani, 2009). The eye infected may be is carried out by intraocular invasion through of microorganisms that are the blood stream or external source. External bacterial infections of the eye are usually localized but may frequently spread to other tissues (Bharathi et al., 2015). Ophthalmic infections can cause damage to structures of the eye, which can lead to vision loss and even blindness if left untreated (Joseph et al., 2009). Staphylococcus aureus, Streptococcus epidermis and Pseudomonas aeruginosa are opportunistic pathogens which have clinical significance in ophthalmology to the fact that they are causes of most eye infections 
(Kwapong et al., 2013). Bacterial colonization on contact lenses and its solutions may be also causes inflammation of eye.

The complications of contact lens include acute red eye, peripheral ulcers, infiltrative keratitis and asymptomatic keratitis (Shaharuddin et al., 2009). It is well known that the deposits on contact lenses consist of proteins, lipids and mucin as tear components which stimulate the growth of microorganisms on its surfaces. Protein deposits are natural deposits on contact lenses which are unavoidable as they are formed by the interaction of the protein in our natural tears and the contact lenses. Contact lens cleansing solutions have been prepared using plant (papain) and animal (pancreatin, trypsin and chemotrypsin) proteases (Ashwini et al., 2014).

The effective use of antibiotics to treat ophthalmic infections requires an understanding of the disease and the pharmacokinetics and pharmacodynamics of the drugs used for the treatment. The failure of these antibiotics has resulted for man to search for more effective sources of natural products from plants and some insects (Omoya et al., 2011); such as honey, tea, probiotic. a rekindled interest in the pharmaceutical importance of plants has led to the discovery and adaptation of plant extracts which were commonly used in traditional medicine as alternative source of remedy (Roopal et al., 2011).

Antimicrobial agents are the substances known to have therapeutic effect on microorganisms either as a control, prevention or cure of microbial and nonmicrobial disease origin. These antimicrobial agents are synthesized chemotherapeutic substances obtained majorly from microorganisms, plants and some animal products (Alkhyat et al., 2017). This study aimed to prove the fact traditional treatment uses which derived from natural sources and that popular in developing countries against isolates caused by ocular infections.

The objectives of current study includes to isolate and diagnosis only Gram negative bacteria among people are suffering from discharges from the eye (whether lenses users or not), and to study the inhibitory effect of certain antibiotics on isolates and compare it with the effect natural agents. Also to investigate the antibacterial activity of black and green tea, honey and CFS of Lactobacillus casei on Gram negative bacteria that isolated from the eye infections.

\section{Materials and Methods}

\section{Bacterial sample}

\section{Eye samples collection}

A total of 30 eye swabs were collected between November and December 2014 from persons who sufferers eyes mucous discharge (patients who wearing lenses and not wearing lenses previously). Fifteen samples taken from Al-Kadhimiya Teaching Hospital in Baghdad from patients have eye inflammation but do not use lenses and another 15 samples from students wearing soft contact lenses from Al-Mustansiriyha University.

\section{Inoculation of samples}

By using appropriate sterile moistened swabs, the discharges from eyes were taken carefully; and placed in sterile saline test tubes, then transported to the laboratory within an hour's. Each swab obtained was inoculated into separate tubes with brain heart infusion (BHI) incubated at $37^{\circ} \mathrm{C}$ for 24 hours.

\section{Identification of the Bacterial isolates}

The isolates gently culturing on MacConkey's agar then incubated at $37^{\circ} \mathrm{C}$ for $24 \mathrm{hrs}$ (Figure 
1). According to the manufacturer's instructions, single colonies performed through streaking for identification by Vitek-2 system for final identification (Table 1 and Figure 1).

\section{Antibiotic sensitivity test}

The susceptibility of isolates to antimicrobial agents was examined by an agar diffusion method using paper disks containing the following antibiotic concentrations: cefixime $(5 \mu \mathrm{g})$, meropenem $(10 \mu \mathrm{g})$, Gentamicin (10 $\mu \mathrm{g})$, chloramphenicol (30 $\mu \mathrm{g})$, oxytetracyciine $(30 \mu \mathrm{g})$ and erythromycin $(15 \mu \mathrm{g})$ Isolates were categorized as sensitive (S), moderately sensitive (I), and resistant (R), based upon the interpretive criteria developed by the Clinical and Laboratory Standards Institute (CLSI) (CLSI, 2013).

\section{Assay of antibacterial activity by using agar well diffusion method}

After solidification of Petri plates containing sterile Mueller Hinton agar $20 \mathrm{ml}$, few colonies $(2$ - 4) from overnight culture were transferred to $2 \mathrm{ml}$ of normal saline to prepare the bacterial suspension of each isolate and were adjusted to $(0.5 \mathrm{McF}$ arland standard turbidity) equal to $1.5 \times 10^{8} \mathrm{CFU} / \mathrm{ml}$. Then the plates were swabbed of each bacterium isolate suspension. Thus were left at room temperature for 15 minutes allowing the absorption of the inoculums into the agar. Wells of $5 \mathrm{~mm}$ size were made with sterile cork borer into agar plates containing the bacterial inoculums.

Using the micropipette $50 \mu \mathrm{l}$ volume of the extract was added into a well of inoculated plates. Sterilized distilled water was used as a negative control which was introduced into a well instead of extract. Plates incubated at 37 $\mathrm{C}^{\mathbf{o}}$ for overnight. The diameter of the zones of inhibition was measured with scale (Kumar et al., 2010).

\section{Cell free supernatants of LAB}

\section{Isolation of lactic acid bacteria}

$1 \mathrm{ml}$ of milk sample was collected during lactation from healthy mother in a sterile tube by using sterile gloves. Previously, nipples and mammary areola were cleaned with soap and sterile water. The first drops were discarded. The sample was kept until delivery to the laboratory (Soto et al., 2014). Appropriate dilutions of the collected milk sample was made in normal saline and pour plated on MRS agar and incubated at $37^{\circ} \mathrm{C}$ an aerobically for 24 to 48 hours. At the end of 48 hours, when the colonies became predominant, morphologically distinct and well isolated colonies were picked and transferred to new MRS agar plates by streaking. Colonies showing typical characteristics of lactobacilli on agar surface were picked up randomly and transferred into MRS broth for further enrichment. Further, their purity was checked on MRS agar (Mithun et al., 2015).

\section{Identification of Lactobacillus species}

The growing Lactobacillus casei colonies were subjected to the following identification according to their morphological, cultural, and physiological and biochemical characteristics by the procedures as described in Bergey's Manual of Systematic Bacteriology. Colonies differ in morphology, pigmentation; shape and size.

Initially all of the isolates were examined for Gram staining and catalase production. Only the Gram positive, catalase-negative and rod shape isolates were then purified by streak plating using the same medium. After several subcultures, finally the single colonies of Lactobacillus was isolated by observing their colony morphology and some biochemical tests (carbohydrate fermentations, arginine 
hydrolysis, $\mathrm{CO}_{2}$ production and growth at different temperatures $15^{\circ} \mathrm{C}, 45^{\circ} \mathrm{C}$ ) (Bhardwaj et al., 2012; Davoodabadi et al., 2015; Serrano et al., 2016).

\section{Preparation of cell- free supernatants}

CFS of Lactobacillus were obtained by centrifugation (5000 rpm for $20 \mathrm{~min}$ ) of $20 \mathrm{ml}$ MRS broth that containing growth Lactobacillus casei, the supernatant was filtered through a $0.22 \mathrm{~mm}$ filter to remove cells (Al-Fraji, 2013).

\section{Collection of plants}

\section{Tea}

The dried leaves of SILANI black tea and green tea (Camellia sinensis), the granules form was purchased from market in Baghdad, Iraq.

\section{Aqueous extracts preparation}

Ten grams of leaves of green and black tea was soaked in $100 \mathrm{ml}$ boiling distilled water for $10 \mathrm{~min}$. Then the extract was soaking for 2 day, filtered from the leaves by using Whatman filter paper No 1. The filtrate was then centrifuged at the highest speed (3000 rpm) for 15 min. Only supernatant was used (Basam et al., 2016; Al-Fraji et al., 2016).

\section{Collection of honey}

\section{Honey}

Raw honey samples were collected form AlZafaraniyah rural areas in the Baghdad, Iraq. During the collection of honey we used sterile container for transferred to the college laboratory.

\section{Preparation of dilution}

Honey was diluted by using sterile distilled water; $10 \mathrm{~g}$ of honey was placed in $100 \mathrm{ml}$ of
D.W and then mixed well by vortex (Ramalivhana et al., 2014).

\section{Results and Discussion}

Out of 30 samples collected, 20 were showed positive results. Enterobacter cloacae (8) was the main isolated gram-negative bacteria from all ocular infections, followed by Pseudomonas luteola (7), Leclercia adecarboxylata (3) and (2) Pantoea agglomerans; identification by Vitek-2 system are shown in tables 1 and 2 and figure 2 . The results of antibiotic susceptibility test of the eye isolates indicated that high proportion of test organisms were resistant to chloramphenicol, erythromycin, cefixime, while showed few isolates sensitivity to oxytetracycline, gentamicin, meropenem (Table 3 and Figure 3). Antibacterial activity of natural agents (Black tea, green tea, honey, CFS of Lactobacillus casei) were screened against isolates from different bacterial groups of infected eye, using agar well diffusion method (Figure 4, 5, 6, 7).

Black tea extract which recorded inhibition zone from (10 to $24 \mathrm{~mm}$ ) (Table 4), these results provide evidence for the presence of antimicrobial tannic acid is an important inhibitor of bacterial growth and phenolic compounds in tea which are useful in the control of common bacterial infections, These compounds can degrade the cell wall, disrupt the cytoplasmic membrane, damage membrane proteins and interfere with membrane-integrated enzymes, which may eventually lead to cell death. Polyphenolic compounds including catechins and flavonoids (quercetin, kaempferol, myricetin and theirglycosides). Green tea extract which recorded inhibition zones ranged from (11 to $25 \mathrm{~mm}$ ) (Table 4). The properties of green tea which inhibit bacterial growth are mainly related to their flavonoids components including epicatechin, epicatechin gallate, epigallocatechin, and epigallocatechin gallate. 
Table.1 Some general characteristics of isolated bacteria from infected eye in this study

\begin{tabular}{|c|c|c|c|}
\hline Microorganism & Description and Significance & Classification & $\begin{array}{c}\text { Phenotypic } \\
\text { Characteristics } \\
\end{array}$ \\
\hline Enterobacter cloacae & $\begin{array}{l}\text { is a rod-shaped, gram-negative } \\
\text { bacteria, normal gut flora of } \\
\text { many human, Nosocomial } \\
\text { pathogens that can cause a } \\
\text { range of infections such as } \\
\text { bacteremia, lower respiratory } \\
\text { tract infection, Urinary tract } \\
\text { infections. }\end{array}$ & $\begin{array}{c}\text { Enterobacteriaceae } \\
\text { Family }\end{array}$ & $\begin{array}{c}\text { Non-lactose } \\
\text { fermentation on } \\
\text { macconkey agar }\end{array}$ \\
\hline Pseudomonas luteola & $\begin{array}{l}\text { is a Gram-negative, motile by } \\
\text { multitrichous flagella, found in } \\
\text { damp environments, aerobe. } \\
\text { They grow as rods, It is } \\
\text { an opportunistic pathogen that } \\
\text { can cause bacteremia, } \\
\text { meningitis, prosthetietic. }\end{array}$ & $\begin{array}{c}\text { Pseudomonadaceae } \\
\text { Family }\end{array}$ & $\begin{array}{c}\text { Non-lactose } \\
\text { fermentation on } \\
\text { macconkey agar }\end{array}$ \\
\hline $\begin{array}{l}\text { Leclercia } \\
\text { adecarboxylata }\end{array}$ & $\begin{array}{l}\text { is Gram-negative, facultative- } \\
\text { anaerobic, peritrich-flagellated } \\
\text { bacilli, isolated from food, } \\
\text { water and other environmental } \\
\text { sources. is a pathogen } \\
\text { associated with water } \\
\text { environments can causes } \\
\text { bacteremia, wound infections. }\end{array}$ & $\begin{array}{c}\text { Enterobacteriacae } \\
\text { Family }\end{array}$ & $\begin{array}{l}\text { lactose } \\
\text { fermentation on } \\
\text { macconkey agar }\end{array}$ \\
\hline Pantoea agglomerans & $\begin{array}{l}\text { is a facultative anaerobic, rod- } \\
\text { shaped bacterium is a Gram- } \\
\text { negative bacterium causing } \\
\text { wound, blood, respiratory tract } \\
\text { infection and urinary-tract } \\
\text { infections. It is commonly } \\
\text { isolated from animal or human } \\
\text { feces. It is reported as both } \\
\text { commensal and opportunistic } \\
\text { pathogen. The main } \\
\text { transmission path is direct or } \\
\text { indirect contact with } \\
\text { contaminated persons or } \\
\text { objects. }\end{array}$ & $\begin{array}{c}\text { Enterobacteriacae } \\
\text { Family }\end{array}$ & $\begin{array}{l}\text { lactose } \\
\text { fermentation on } \\
\text { macconkey agar }\end{array}$ \\
\hline
\end{tabular}


Table.2 Source and number the isolates from infected eye

\begin{tabular}{|c|c|}
\hline Isolate Source. & NO. \\
\hline Contact lenses users. & $\mathbf{1 0}$ \\
\hline Non-users. & $\mathbf{1 0}$ \\
\hline
\end{tabular}

Table.3 Antibiotic susceptibility test of the bacterial isolates

\begin{tabular}{|c|c|c|c|c|c|c|}
\hline Ocular Bacterial Isolates & $\mathbf{C}$ & $\mathbf{G}$ & $\mathbf{E}$ & CXM & MEM & $\mathbf{T}$ \\
\hline Enterobacter cloacae1 & $\mathrm{R}$ & $\mathrm{R}$ & $\mathrm{R}$ & $\mathrm{R}$ & $\mathrm{R}$ & $\mathrm{S}$ \\
\hline Enterobacter cloacae 2 & $\mathrm{R}$ & $\mathrm{S}$ & $\mathrm{R}$ & $\mathrm{R}$ & $\mathrm{S}$ & $\mathrm{S}$ \\
\hline Enterobacter cloacae 3 & $\mathrm{R}$ & $\mathrm{S}$ & $\mathrm{R}$ & $\mathrm{R}$ & $\mathrm{R}$ & $\mathrm{R}$ \\
\hline Enterobacter cloacae 4 & $\mathrm{R}$ & $\mathrm{R}$ & $\mathrm{R}$ & $\mathrm{R}$ & $\mathrm{R}$ & $\mathrm{R}$ \\
\hline Enterobacter cloacae 5 & $\mathrm{R}$ & $\mathrm{R}$ & $\mathrm{R}$ & $\mathrm{R}$ & $\mathrm{R}$ & $\mathrm{S}$ \\
\hline Enterobacter cloacae 6 & $\mathrm{R}$ & $\mathrm{R}$ & $\mathrm{R}$ & $\mathrm{R}$ & $\mathrm{R}$ & $\mathrm{S}$ \\
\hline Enterobacter cloacae 7 & $\mathrm{R}$ & $\mathrm{R}$ & $\mathrm{R}$ & $\mathrm{R}$ & $\mathrm{R}$ & $\mathrm{R}$ \\
\hline Enterobacter cloacae 8 & $\mathrm{R}$ & $\mathrm{R}$ & $\mathrm{R}$ & $\mathrm{R}$ & $\mathrm{R}$ & $\mathrm{R}$ \\
\hline Leclercia adecarboxylata 1 & $\mathrm{R}$ & $\mathrm{R}$ & $\mathrm{R}$ & $\mathrm{R}$ & $\mathrm{S}$ & $\mathrm{R}$ \\
\hline Leclercia adecarboxylata 2 & $\mathrm{R}$ & $\mathrm{S}$ & $\mathrm{R}$ & $\mathrm{R}$ & $\mathrm{S}$ & $\mathrm{S}$ \\
\hline Leclercia adecarboxylata 3 & $\mathrm{R}$ & $\mathrm{R}$ & $\mathrm{R}$ & $\mathrm{R}$ & $\mathrm{R}$ & $\mathrm{R}$ \\
\hline Pantoeal & $\mathrm{R}$ & $\mathrm{S}$ & $\mathrm{R}$ & $\mathrm{R}$ & $\mathrm{S}$ & $\mathrm{R}$ \\
\hline Pantoea 2 & $\mathrm{R}$ & $\mathrm{R}$ & $\mathrm{S}$ & $\mathrm{R}$ & $\mathrm{S}$ & $\mathrm{R}$ \\
\hline Pseudomonas luteola 1 & $\mathrm{R}$ & $\mathrm{R}$ & $\mathrm{R}$ & $\mathrm{R}$ & $\mathrm{R}$ & $\mathrm{S}$ \\
\hline Pseudomonas luteola 2 & $\mathrm{R}$ & $\mathrm{R}$ & $\mathrm{R}$ & $\mathrm{R}$ & $\mathrm{S}$ & $\mathrm{S}$ \\
\hline Pseudomonas luteola 3 & $\mathrm{R}$ & $\mathrm{S}$ & $\mathrm{R}$ & $\mathrm{R}$ & $\mathrm{R}$ & $\mathrm{R}$ \\
\hline Pseudomonas luteola 4 & $\mathrm{R}$ & $\mathrm{R}$ & $\mathrm{R}$ & $\mathrm{R}$ & $\mathrm{R}$ & $\mathrm{R}$ \\
\hline Pseudomonas luteola 5 & $\mathrm{R}$ & $\mathrm{R}$ & $\mathrm{R}$ & $\mathrm{R}$ & $\mathrm{R}$ & $\mathrm{R}$ \\
\hline Pseudomonas luteola 6 & $\mathrm{R}$ & $\mathrm{S}$ & $\mathrm{R}$ & $\mathrm{R}$ & $\mathrm{S}$ & $\mathrm{R}$ \\
\hline Pseudomonas luteola 7 & $\mathrm{R}$ & $\mathrm{R}$ & $\mathrm{R}$ & $\mathrm{R}$ & $\mathrm{R}$ & $\mathrm{R}$ \\
\hline
\end{tabular}

Chloramphenicol, C; gentamicin, G; erythromycin, E; Cefixime, CXM; meropenem, MEM; oxytetracycline, T; Sensitive S; Resistance R 
Figure.1 Enterobacter cloacae, Leclercia adecarboxylata, Pseudomonas luteola, pantoea agglomerans on MacConkey agar
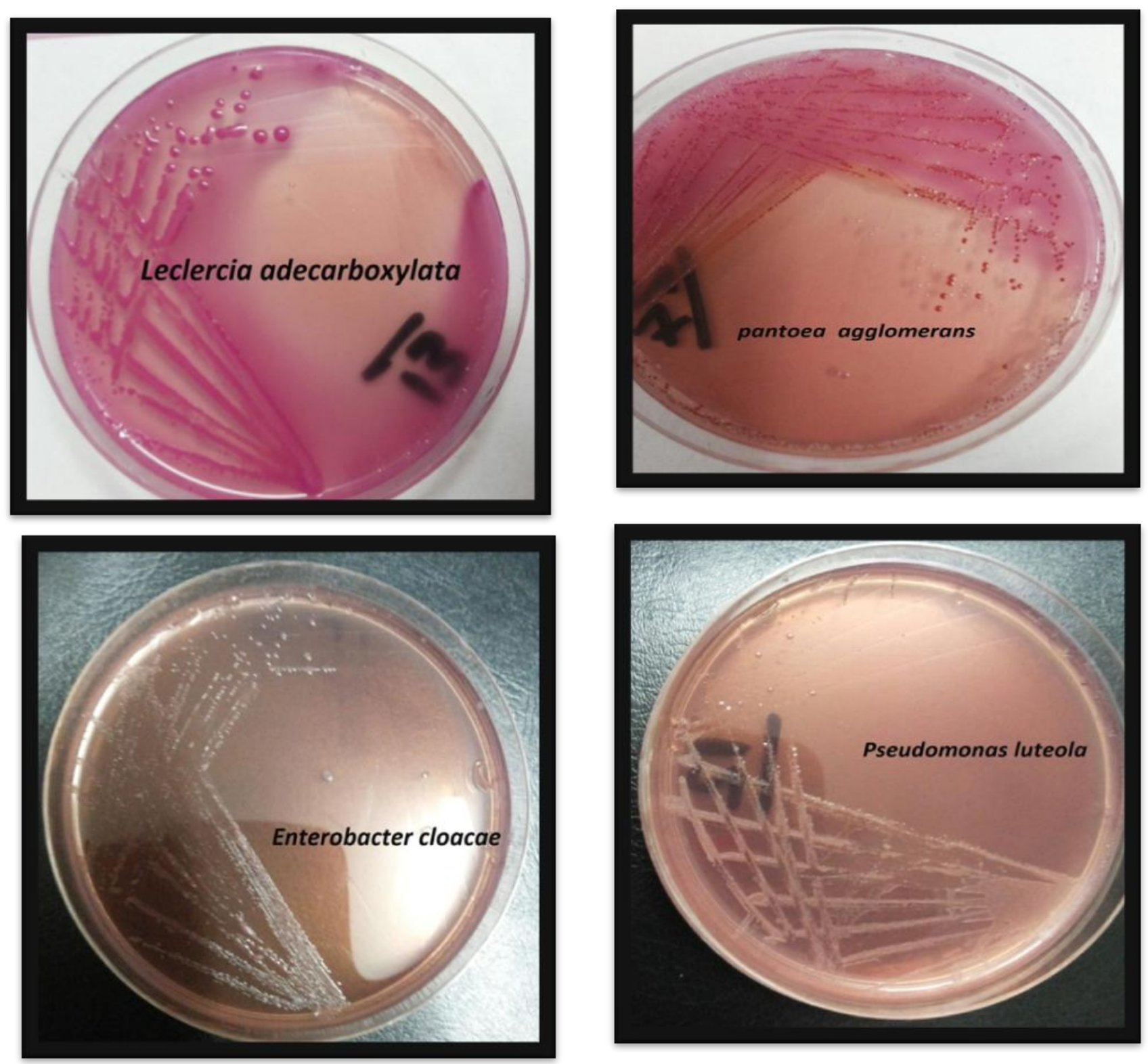
Table.4 The Antibacterial Activity of Natural agents Against Infected Eye Isolates

\begin{tabular}{|c|c|c|c|c|}
\hline \multirow{3}{*}{ Isolates } & \multicolumn{4}{|c|}{ Antibacterial activity } \\
\hline & Black tea & Green tea & Honey & Probiotic \\
\hline & \multicolumn{4}{|c|}{ Zone of inhibition (mm) } \\
\hline Enterobacter cloacae 1 & 11 & 20 & 15 & 15 \\
\hline Enterobacter cloacae 2 & 12 & 18 & 15 & 16 \\
\hline Enterobacter cloacae 3 & 12 & 20 & 18 & 15 \\
\hline Enterobacter cloacae 4 & 10 & 25 & 22 & 23 \\
\hline Enterobacter cloacae 5 & 12 & 20 & 18 & 16 \\
\hline Enterobacter cloacae 6 & 10 & 20 & 18 & 13 \\
\hline Enterobacter cloacae 7 & 15 & 20 & 21 & 18 \\
\hline Enterobacter cloacae 8 & 13 & 20 & 22 & 20 \\
\hline Pseudomonas luteola 1 & 11 & 13 & 26 & 20 \\
\hline \begin{tabular}{|l|} 
Pseudomonas luteola 2 \\
\end{tabular} & 11 & 20 & 20 & 15 \\
\hline Pseudomonas luteola 3 & 12 & 18 & 21 & 15 \\
\hline Pseudomonas luteola 4 & 14 & 25 & 23 & 15 \\
\hline Pseudomonas luteola5 & 11 & 18 & 20 & 16 \\
\hline Pseudomonas luteola 6 & 12 & 18 & 30 & 13 \\
\hline Pseudomonas luteola 7 & 10 & 17 & 25 & 25 \\
\hline Leclercia adecarboxylata1 & 10 & 11 & 27 & 17 \\
\hline Leclercia adecarboxylata2 & 10 & 12 & 30 & 18 \\
\hline Leclercia adecarboxylata3 & 10 & 12 & 25 & 18 \\
\hline Pantoea 1 & 15 & 25 & 30 & 20 \\
\hline Pantoea 2 & 24 & 14 & 25 & 20 \\
\hline
\end{tabular}

Figure. $2 \%$ the percentage distribution of bacteria in isolates eye

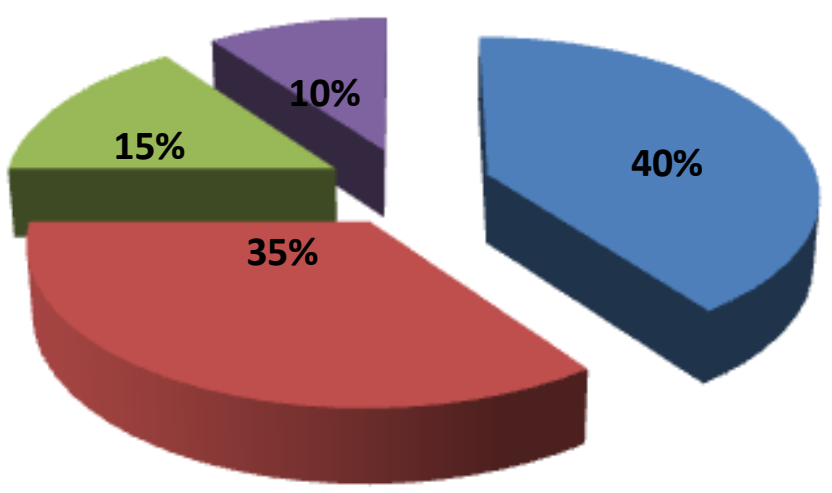

- Enterobacter cloacae

- Pseudomonas luteola

Leclercia adecarboxylata

- pantoea agglomerans 
Figure.3 Antibiotic susceptibility test of the bacterial isolate

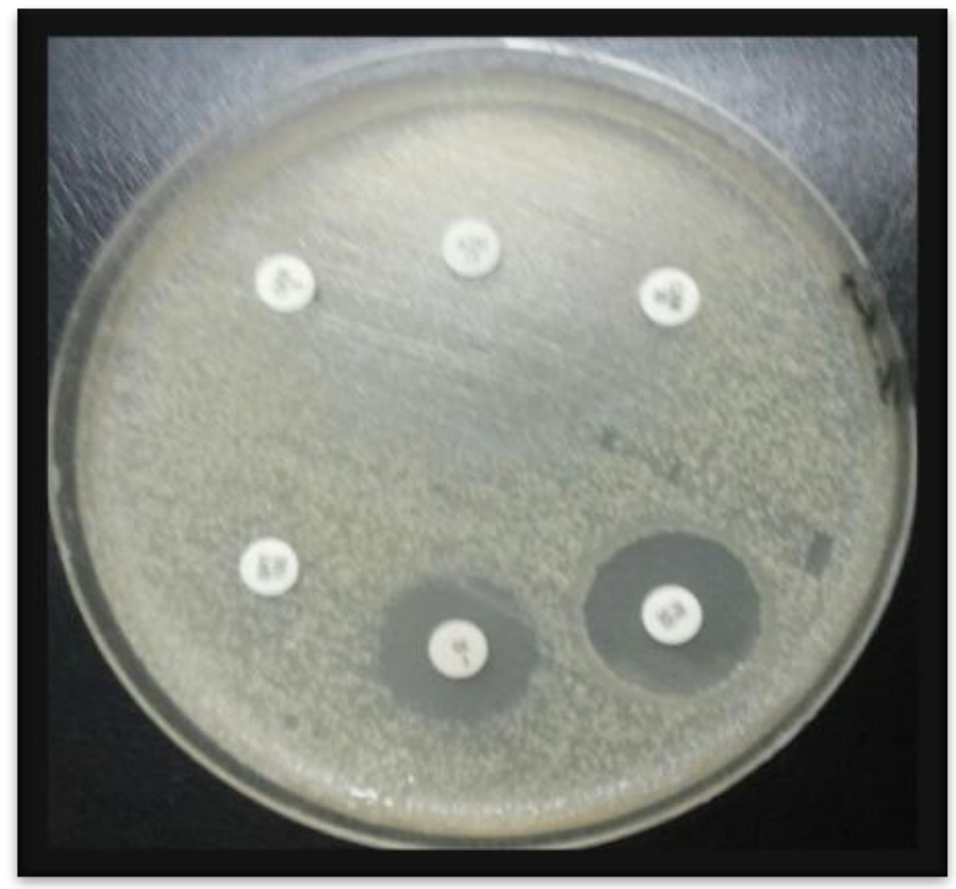

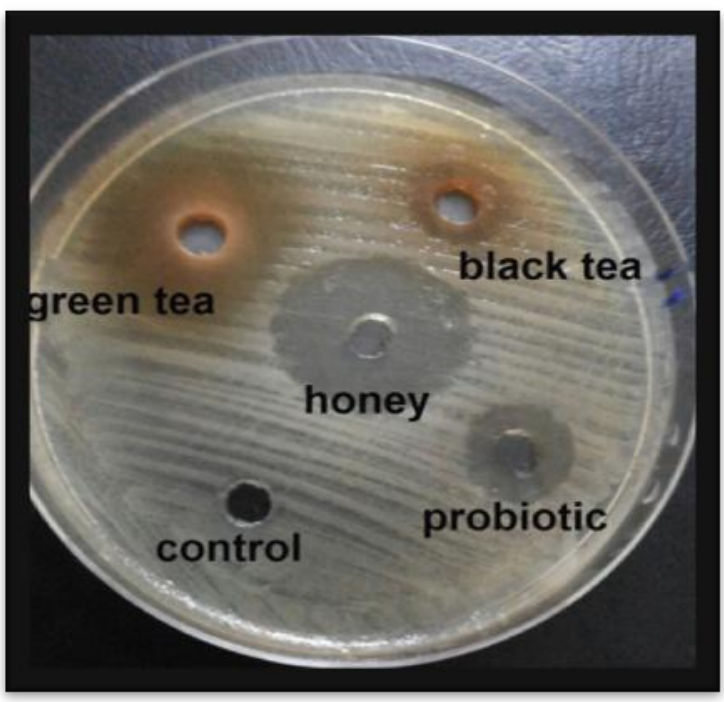

Figure.4 Antibacterial activity of 4 Natural agent against Enterobacter cloacae

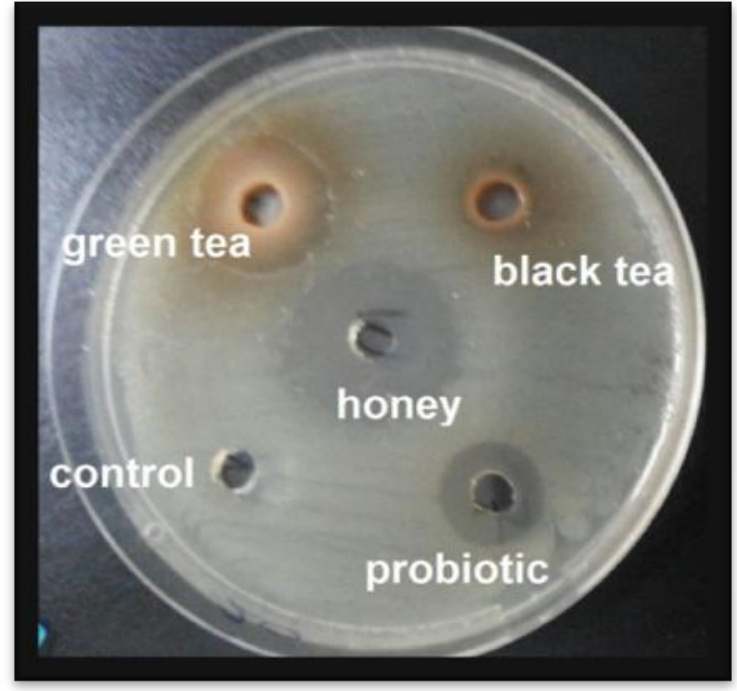

Figure.5 Antibacterial activity of 4 Natural agent against Pseudomonas luteola 


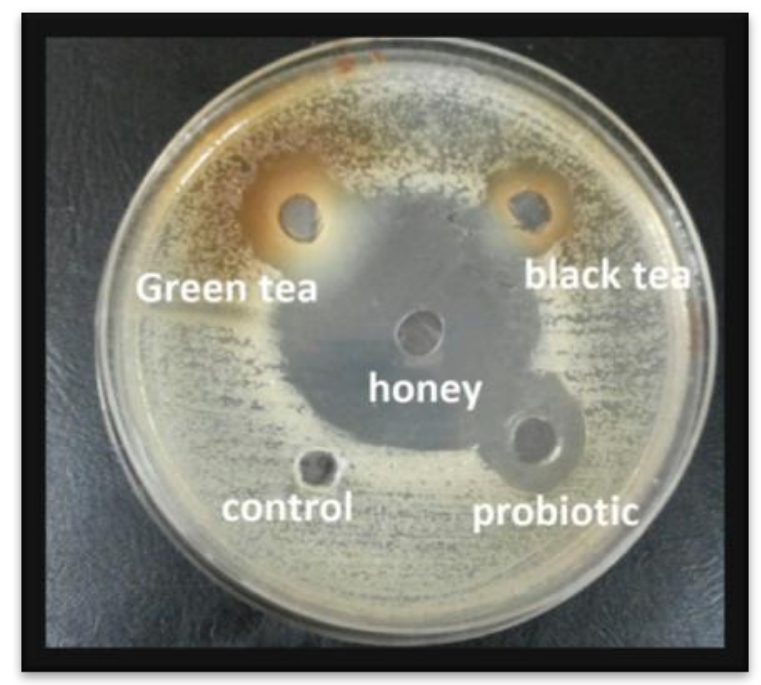

Figure.6 Antibacterial activity of 4 natural agent against Leclercia adecarboxylata

Mechanism of action of green tea leaves extract has been proposed that green tea can prevent the attachment of pathogenic bacteria on the host cell membrane. Thus, green tea extract inhibits the adhesion of bacteria on host cell surface membranes and acts as a potential anti adhesive agent (Maksum et al., 2013). Tea intake is second to water in terms of worldwide popularity as a beverage, green and black tea comes from the leaves of the plant Camellia sinensis. The antimicrobial activity of green tea was recognized about 90 years ago (Mervat et al., 2007). The boiling water extract of green tea was effective to oral bacteria, especially periodontal pathogens, so its use as mouthwash for the treatment of periodontitis in Pregnant Women (Enas, 2014).

CFS of Lactobacillus casei give us from (13 25) $\mathrm{mm}$ (Table 4). Antimicrobial action of Lactobacilli is production of different antimicrobial metabolites such as organic acids, $\mathrm{H}_{2} \mathrm{O}_{2}$, bacteriocins ${ }^{\mathbf{2 6}}$. LAB produce lactic acid and other organic acids thus lower the $\mathrm{pH}$ of the environment and inhibit the growth of the bacterial pathogens, Lactobacillus is penetrate of the bacterial

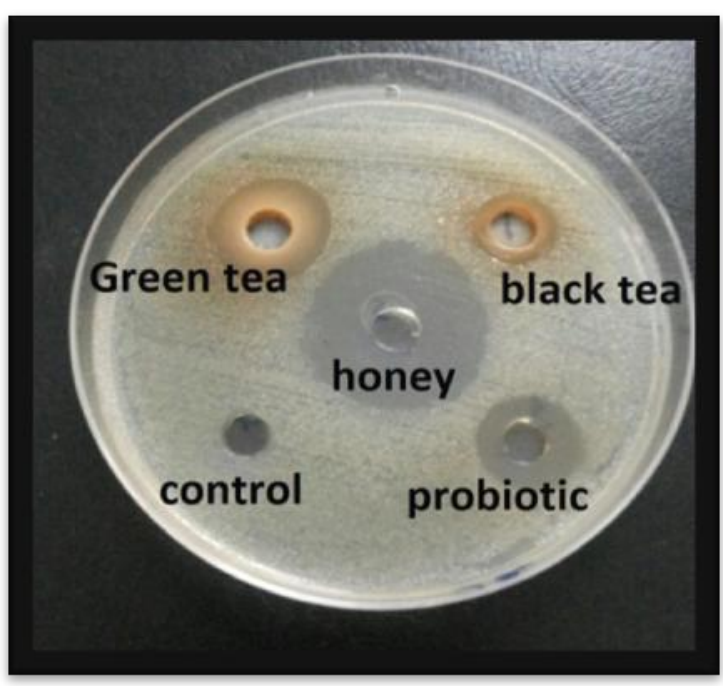

Figure.7 Antibacterial activity of 4 natural agent against Pantoea

outer membrane. Hydrogen peroxide inhibits both Gram-positive and Gram-negative organisms. While bacteriocin, is family includes a wide variety of peptides and proteins, microbial targets, it has important role in immunity (Pithva et al., 2011).

While honey which recorded high inhibition zones ranged from $(15-30) \mathrm{mm}$ (Table 4). The fact that inhibition of bacterial pathogens by honey was superior, over the most common antibiotics used to treat bacteria, makes them a novel source of anti microbial agents. Previous studies confirmed the antimicrobial activity of honey against a wide range of microbes like multidrug resistant pathogens (Uzma et al., 2014).

The antibacterial nature of honey depends on different factors acting singularly or synergistically, which are phenolic compounds, $\mathrm{H}_{2} \mathrm{O}_{2}$, complex carbohydrates, $\mathrm{pH}$ of honey and osmotic pressure exerted by the honey itself also. It has been documented that the pronounced antibacterial activity and bactericidal factors due to presence the methylglyoxal (MGO) in honey (José et al., 2014; Paulus et al., 2010). In Ghana, it is a 
common practice to see traditionalists instilling few drops of the honey on the eyes of patients presenting with conjunctival redness.

In conclusion the results of this study showed:

Novel eye isolates as Enterobacter cloacae, Pseudomonas luteola, Leclercia adecarboxylata and pantoea agglomerans.

The isolates were resistant to most antibiotics that used.

Compared to selected antibiotics that used, the natural agents are more effectively on all isolated contrast to antibiotics.

\section{Recommendations}

Natural components and the ethnobotanicals have been used since the early days of humankind and are still used throughout the world for health promotion and treatment of disease. Most of drugs prescribed worldwide are derived from plants. For that we recommend Extraction and purification of active substances of natural materials substances that were used in this study and add in the pharmaceutical industry in different ways and forms, and they include the essential oils, eye ointments or even solutions for soft contact lenses under systematic approach to assess their safety and effectiveness. And also need more research studies are required about correlation eye infections with soft contact lenses.

\section{Acknowledgment}

The authors would like to thank ALMustansiriyah University (www.uomustansiriyah.edu.iq) Baghdad -Iraq for them assistance in this project. University website: www.uomustansiriyah.edu.iq

\section{References}

Abd, A.A., Ibrahium, M.I., Al-Atrouny, A.M. 2011. Effect of black tea on some cariogenic bacteria. World Appl. Sci. J., 2(4): 552-558.

Al-Fraji, B.B., Enas, I.J., Rasha, M.S., Enaam, H.B. 2016. Effects Of Some Traditional Plants Extracts On Bacteria Isolated From Burns, Wounds and Skin Diseases. World J. Pharma. Res., 5(6): 63-74.

Al-Fraji, B.B.M. Study of the effect of selected commercial detergents (Soap, Wet wipes) and probiotic Lactobacillus against bacteria isolated from paper currencies in Baghdad, Iraq. Int. J. Adv. Res., 3(3): 522-532.

Alkhyat S.H., Al -Maqtari, M.A. Effectiveness of antibiotics blended with honey on some pathogenic bacteria species, Int. J. Microbiol. Immunol. Res., 2(7): 109-115.

Ashwini, A.J., Khatib, S.I., Mahesh, A.H., Shashikant, V., Gadreand, M., Williamson, T. 2014. Study of protease enzyme from bacillus species and its application as a contact lens cleanser. $J$. British Biomed. Bull., 2(2): 293-302.

Baqer, Y.M., Mohammed, B.B., Obaid, K.A. 2014. CFS OF Lactobacillus: A Natural Agent against Bacterial Contamination Of Cosmetics Tools, I.J.A.B.R., 4(3): 258264.

Basam, B.M., Enas, I.J., Enaam, H.B., Zainab, H.S., Khitam, A.O. 2016. Antimicrobial Effects of Rubus idaeus, Origanum vulgare, Petroselinum crispum and Bacteria Infecting Urinary Tract. IJOPILS, 4(2): 1-17.

Bharathi, M.J., Ramakrishnan, R., Shivakumar, C., Meenakshi, R., Lionalraj, D. 2015. Etiology and antibacterial susceptibility pattern of community-acquired bacterial ocular infections in a tertiary eye care hospital in south India. Indian $J$. Ophthalmol., 58(6): 497-507.

Bhardwaj, A., Puniya, M., Sangu, K.P.S. 2012. Isolation and Biochemical Characterization of Lactobacillus species 
Isolated from Dahi. Research and Reviews: A J. Dairy Sci. Technol., 1(2): 1-14.

Clinical and Laboratory Standards Institute. 2013. Performance standards for antimicrobial susceptibility testing: twenty-third informational supplement m100-s23, Clsi, Wayne, Pa, Usa.

Dagnachew, M., Yitayih, W., Feleke, M., Tesfaye, N. and Getachew, F. Types and drug susceptibility patterns of bacterial isolates from eye discharge samples at Gondar University Hospital, Northwest Ethiopia. BMC Res. Notes, 7(292): 1-5.

Davoodabadi, A., Dallal, S.M.M., Lashani, E., Ebrahimi, M.T. 2015. Antimicrobial Activity of Lactobacillus spp. Isolated From Fecal Flora of Healthy Breast-Fed Infants Against Diarrheagenic Escherichia coli. Jundishapur J. Microbiol., 8(12): 1-11.

Enas, Y.S. 2014. Antibacterial effect of black and green tea on oral bacteria in pregnant. Int. J. Enhanced Res. Sci. Technol. Engi., 3(4): 1-14.

José, M., Alvarez, S., Massimiliano, G., Tamara, Y.F., Luca, M., Francesca, G. 2014. The composition and biological activity of honey: a focus on manuka honey. Review Food J., 3: 420-432. www.mdpi.com/journal/foods

Joseph, S., Bertino, Jr. 2009. Impact of antibiotic resistance in the management of ocular infections: the role of current and future antibiotics, Clin. Ophthalmol., dove medical press to scientific and medical research, 3: 507-521.

Kumar, S., Narain, S. 2010. Herbal remedies of wetlands macrophytesin India. Int. J. Pharm. Biosci., 1(2): 1-12.

Kwapong, P.K., Ilechie, A., Kusi, R. 2013. Comparative antibacterial activity of stingless bee honey and standard antibiotics against common eye pathogens. J. Microbial. Biotech. Res., 3(1): 162-168.

Maksum, R., Rafael, A.A., Berna, E., Conny, R.T. 2013. Antimicrobial activity of green tea extract against isolates of methicillin resistant staphylococcus aureus and multidrug resistant pseudomonas aeruginosa. Asian Pacific J. Trop. Biomed., 3(8): 663667.

Mervat, A.K., Nourhan, H.F., Mohamed, A.F., Fatma, S.E. 2007. Dabbous effect of green tea extract on some virulence factors of selected multi resistant clinical isolates. Egyptian J. Med. Microbiol., 16(3): 461-471.

Mithun, S., Dipak, V. and Sheela, S. 2015. Isolation and Identification Of Lactobacilli From Raw Milk Samples Obtained From Aarey milk colony. Int. J. Scientific and Res. Publications, 5(4): 15.

Omoya, F.O., Akharaiyi, F.C. Mixture of honey and ginger extract for antibacterial assessment on some clinical isolates, Int. J. Pharma. Biomed. Res., 2(1): 39-47.

Paulus, H.S.K., Anje, A., Velde, Te, Leonie, D.B., Dave, S., Christina, M.J.E., Vandenbroucke, G., Sebastian, A.J.Z. 2010. How honey kills bacteria. FASEB J., 24: $2576-2582$.

Pithva, S., Ambalam, P., Dave, J. 2011. Antimicrobial peptides of probiotic lactobacillus strains science against microbial pathogens: Communicating Curr. Res. Technol. Adv., 987-991.

Ramalivhana, J.N., O.B.I. C., Samie, A., Iweriebor, B., Uaboi-Egbenni, P., Idiaghe, J.E. And Momba, M.N. 2014. Antibacterial activity of honey and medicinal plant extracts against gram negative microorganisms. African $J$. Biotechnol., 13(4): 616-625.

Roopal, V.P., Vidhi, T.T., Patel, V. Antimicrobial activity of ginger and honey on isolates of extracted carious teeth during orthodontic treatment. Asian Pacific J. Trop. Biomed., 58-61.

Serrano, J.C.N., Solís, P.J.R. 2016. Isolation and Identification of Lactic Acid Bacteria from Human Milk with Potential Probiotic Role. J. Food and Nutrition Res., 4(3): 170-177.

Shaharuddin, B., Chan, Kw., Noor, S.M., Embong, Z. 2009. Bacterial colonization 
of hydrogel disposable contact lenses. Int. J. Ophthalmol., 2(2): 158-161.

Soto, A., Martin, V. and others. 2014. Lactobacilli and Bifidobacteria in Human Breast Milk: Influence of Antibiotherapy and Other Host and Clinical Factors. $J P G N$, 59: 78-88.

Ubani, U. 2009. Common bacterial isolates from infected eyes, JNOA, 15: 40-47.

Uzma, A.A., Shaukat, A., Saiqa, A. A comparative study of antibacterial and antioxidant activities of wild honey (sunflower and eucalyptus)and commercial honey. J. Pharma. Sci. Pharmacol., 2: 1-8.

\section{How to cite this article:}

Enas Ibrahim Jasim, Basam Basim Al-Fraji and Duaa Suhail Shawket. 2017. Lactobacillus casei Isolated From Human Milk and Three Natural Agents Act as Antibacterial Against Gram Negative Pathogenic Bacteria Isolated From Infected Eye. Int.J.Curr.Microbiol.App.Sci. 6(4): 2568-2580. doi: https://doi.org/10.20546/ijcmas.2017.604.299 